\title{
0 abade Grégoire, o Haiti e o Brasil: repercussões no raiar do século XIX.
}

Abbott Gregóire, Haiti and Brazil:

Repercussions on the Eve of the 19th Century

\section{Marco Morel}

Doutor em História pela Université de Paris I e Professor do Departamento de História da Universidade do Estado do Rio de Janeiro.

\section{Resumo}

As idéias do abade francês Henri Grégoire (1750 - 1831), revolucionário de 1789, sobre a Revolução do Haiti (1791 - 1825), abolição da escravatura, preconceito racial e dominação colonial européia tiveram importância e impacto em sua época e repercutiram no Brasil de forma diversificada, entre o clero brasileiro e no âmbito de disputas sociais e políticas no período das Regências. Grégoire analisava a sociedade escravista brasileira e foi um dos propagadores da discussão do modelo político haitiano no início do século XIX.

\section{Abstract}

The ideas of the French abbot Henri Grégoire (1750-1831) - a revolutionary of 1789 - concerning the Haitian Revolution (1791-1825), the abolition of slavery, racial prejudice and European colonial domination had, in his times, great importance and impact, reverberating in Brazil in multifarious forms, not only among the clergy but also in social and political disputes during the Regency period. Grégoire, in his writings, devoted himself to analyzing Brazilian slavocratic society and was also responsible, in the beginning of the $19^{\text {th }}$ century, for disseminating the discussion of the Haitian political model.

\section{Palavras-chave}

Haiti/São Domingos, revolução, história intelectual, abolição da escravatura, Iluminismo, Regência.

\section{Keywords}

Haiti/Saint Domingue, revolution, intellectual history, abolition of slavery, Enlightenment, Regency. 
1

A perspectiva de definir conceitualmente em termos históricos a Revolução do Haiti está presente em historiadores como C.L.R. James. Os Jacobinos Negros. Toussaint L'Ouverture e a Revolução de São Domingos. São Paulo, Boitempo Editorial, $2000\{1938\}$; Eugene Genovese. Da Rebelião à Revolução: as revoltas de escravos nas Américas. São Paulo, Global, 1983 e David Geggus. (dir.). The Impact of the Haitian Revolution in the Atlantic World. Columbia: Univ. of South Carolina, 2001.

\section{2}

Para uma abordagem inicial, entre os trabalhos que tratam do assunto, temos: Luiz R. B. Mott. "A Revolução dos negros do Haiti e o Brasil", Historia: Questões \& Debates, Curitiba, 3(4), 1982. Flávio dos Santos Gomes e Marco Morel. "Trajetórias atlânticas: dois brasileiros no Haiti no início dos oitocentos", em Sandra Pesavento (org.). História Cultural - Experiências de Pesquisa, Porto Alegre: UFRGS, 2003.

Cf. verbete "Abbé" em Jean le Rond D'Alembert. Encyclopédie ou Dictionnaire raisonné des sciences, des arts et des métiers $\{1751-1772\}$, edição integral em CD-Rom, Marsanne: Edition Redom, s.d.
Foram intensas as relações entre a Revolução Francesa (1789 - 1799) e a Revolução do Haiti (1791 - 1825), por motivos evidentes, como o fato de que a ilha de São Domingos era considerada a pérola das Antilhas entre as colônias francesas, e que a insurreição dos escravos que desaguou na destruição, ao mesmo tempo, da escravidão e da dominação colonial naquelas paragens foi cronologicamente entrelaçada ao processo revolucionário francês, trazendo à tona suas mais agudas contradições e limites. Da mesma maneira, as repercussões destas revoluções se entrecruzavam dos dois lados do Atlântico e se espalhavam, por sua vez, a outras localidades. Ambas, portanto, faziam parte da chamada Era das Revoluções, na medida em que consideramos a Revolução Francesa num sentido estrito, específico de uma nação - embora saibamos que suas dimensões e repercussões tenham sido amplas, marcando o início da Era Contemporânea 1.

Sabemos que o Haiti foi o segundo país das Américas a proclamar-se independente, em 1804, concretizando um modelo de Independência que seria, em seus momentos iniciais, diferente do republicanismo hispanoamericano, do federalismo norte-americano, da autonomia negociada cana-

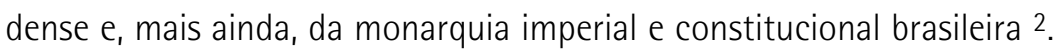

Para analisar mais de perto um aspecto desta questão vasta traremos aqui uma abordagem inicial sobre a obra e o papel do abade francês Henri Grégoire (1750 - 1831) que, situado no epicentro da metrópole colonial em plena Revolução Francesa, relacionou-se com a Revolução do Haiti, do ponto de vista intelectual e político, participando, assim, da discussão em torno do modelo haitiano, do mesmo modo que tratava em seus escritos das condições da América portuguesa. Em seguida, traremos pistas das repercussões das idéias do abade Grégoire sobre a escravidão e a Revolução do Haiti no Brasil.

Estamos, pois, no âmbito das reflexões, das atitudes e dos movimentos anti-racistas e anti-coloniais de fins do século XVIII e início do XIX, e da relação da Revolução Francesa e suas heranças com o que os franceses passaram a chamar de "problema colonial" e, ao mesmo tempo, com a escravidão. Tais questões circulavam e eram também discutidas no Brasil - e não apenas numa perspectiva negativa.

0 que era um abade? Tal título era diversificado na França em fins do século XVIII. Originalmente dado aos chefes das abadias (ou mosteiros) de ordens religiosas, seu significado e função se ampliaram com o tempo. Havia vários tipos de abades, inclusive membros do clero secular: os chefes de determinada paróquia com os respectivos cônegos e padres, aqueles que encabeçavam uma paróquia que havia sido bispado, alguns cardeais, os abades regulares, os abades comanditários, os que eram nomeados pelo rei, entre outros. De modo geral, a figura do abade se destacava da maioria do clero, seja pela atividade intelectual ou pela projeção política, constituindo como que figura de peso intermediário entre padres e bispos ${ }^{3}$. 0 abade do qual nos ocupamos aqui, portanto, não era chefe de ordens religiosas ou de mosteiros, mas se incluia nas diferentes classificações que tal título adquiriu na vida eclesiástica, política e intelectual.

Durante a Ilustração setecentista e sobretudo com a Revolução Francesa (convém não confundi-las, apesar das ligações existentes) o clero, em seus niveis de hierarquia, esteve atravessado pelas contradições das sociedades européias. Eram, como se sabe, homens que dominavam o saber letrado, mas que nem por isso ficavam isentos das marcas complexas e 
François Furet. A constituição civil do clero, in (dir.). Dicionário Crítico da revolução Francesa, Rio de Janeiro: Nova Fronteira, 1989, pp. $537-545$.

5

Ver os ensaios de Alberto Soboul, "Os 'Curés Rouges' de 1793" e de Walter Markov, "'Curés Patriotes' e Sans-Culottes no Ano II", em Frederick Krantz (org.), A Outra História. Ideologia e Protesto Popular nos séculos XVII a XIX, Rio de Janeiro: Zahar, 1990, pp. 164 - 190.

6

Cf. Introdução biográfica de Frank Paul Bowman (org.) L'abbé Grégoire, évêque des Lumières, Paris, 1988.

7

Paris: Maradan, 1808.

8

Para história, ideário e principais personagens da Sociedade dos Amigos dos Negros, de Paris, durante a Revolução Francesa, v. Bernard Gainot e Marcel Dorigny. La société des Amis des Noirs, 1788 - 1799. Contribution à l'histoire de l'abolition de l'esclavage, Paris: Unesco / Edicef, 1998. contraditórias das sociedades de Antigo Regime, inclusive partilhando de diferentes aspirações sociais e formulações intelectuais 4.

Tal situação ganhou contornos marcantes durante a crise do Absolutismo e a Revolução Francesa, quando, de um lado, centenas de religiosos identificavam-se com o Antigo Regime e com a Aristocracia, sendo conhecidos as profanações de igrejas e os massacres de clérigos cometidos pelos revolucionários, do mesmo modo que a mobilização religiosa da população camponesa em atividades contra-revolucionárias, como no caso de Vendéia. De outro lado, são expressivas e freqüentes as adesões de setores do clero à Revolução Francesa, já durante os Estados Gerais, quando membros das três ordens (Nobreza, Clero e Povo) em que se dividia juridicamente a sociedade engrossaram as fileiras do Terceiro Estado. São bastante citados os casos envolvendo o chamado clero constitucional, composto por aqueles que comungavam com muitas das premissas liberais e mesmo revolucionárias daqueles tempos 5

Para se compreender o papel do abade Grégoire é preciso levar em conta, ainda, as multifacetadas idéias sobre raça, diversidade e unidade da espécie humana tão debatidas pelos pensadores da Ilustração ao longo do século XVIII, idéias que não eram monolíticas, onde não faltavam afirmações de cunho anti-racista, num entrelaçar mesclado de embate e identificações entre Luzes, expansão da civilização européia, domínio colonial, tráfico de escravos, escravidão e concepções de liberdade. Tais formulações tiveram, em Grégoire, uma de suas expressões mais reconhecidas e difundidas em sua época

\section{Abade Grégoire: a Revolução no presente}

Henri Grégoire, Convencional de 1789 que presidia a sessão do dia 14 de julho quando a Bastilha foi destruida, ficou conhecido como defensor dos direitos dos judeus, dos negros, dos mulatos e dos habitantes das colônias. E até o fim de sua vida este revolucionário francês foi fiel a tais convicções, que incluiam, também, a necessidade de civilizar e esclarecer a todos os povos, nos moldes europeus e cristãos ${ }^{6}$. Grégoire foi bispo da localidade de Blois (na região de Loir-et-Cher), membro do Senado e, ainda, do Institut de France, do qual, aliás, seria excluido durante a Restauração monárquica, em perseguição a suas idéias. E teve envolvimento mais próximo com a Revolução do Haiti.

Sabe-se que Grégoire publicara, em 1808, o livro De la littérature des Nègres ou Recherches sur leurs facultés intellectuelles, leurs qualités Morales et leur littérature; suivies de Notices sur la vie et les ouvrages des nègres qui se sont distingués dans les Sciences, les Lettres et les Arts 7 , onde, aprofundando a via aberta pelos autores enciclopedistas e ilustrados, sustentava que as "insuficiências dos negros" resultavam da condição em que viviam e não de atavismo racial. Esta obra, que procurava exaltar a Ilustração dos negros ao longo da história, era uma expressão erudita das atividades da Sociedade dos Amigos dos Negros, criada em Paris em 1788 pelo abade Brissot, da qual o autor foi um dos membros ${ }^{8}$. Em suas páginas o abade Grégoire usa a expressão "escravidão colonial", para criticar tal instituição.

Logo no início do livro, à guisa de dedicatória e homenagem, Grégoire faz longa lista dos abolicionistas franceses e ingleses, incluindo também alguns nomes de negros e mestiços (sang-mêlés), de norte-americanos, alemães, dinamarqueses, suecos, holandeses, italianos e um espanhol. 

litterature des Nègres..., pp. XI; $282-3$

11

H. Grégoire, Lettre aux citoyens de couleur et Nègres libres, Paris, 1791, pp. 12, apud H. Grégoire, De la litterature des Nègres..., pp. 281.
Lamenta, em seguida, a ausência de outros espanhóis e mesmo de qualquer português nesta lista, pois estes, a seu conhecimento, não consideravam que os negros fizessem parte da grande famille du genre humain 9 . Como exemplo, o abade Grégoire passa a criticar as posições do bispo José Joaquim da Cunha Azeredo Coutinho por sua defesa da escravidão e do tráfico (citado em outra parte deste trabalho).

Na conclusão do livro De la litterature des Negres..., Grégoire explicita o que seria um dos pontos-chave de seu pensamento sobre o assunto: a configuração do modelo haitiano, sua efetiva possibilidade de propagação, e o que considerava como a inexorável libertação dos escravos para o restante das Américas.

"Esse continente americano, asilo da liberdade, se encaminha para uma ordem de coisas que será comum com as Antilhas, e da qual todas as potências não poderão parar o curso. Os Negros reintegrados em seus direitos, pela marcha irresistivel dos acontecimentos, serão dispensados de todo reconhecimento diante desses colonos, aos quais teria sido igualmente fácil e útil de se fazerem amados."10

Ou seja, o caminho para o fim da escravidão poderia ser gradual, feito a partir da compreensão e concessões dos colonos e proprietários, ou poderia ser violento e brusco, como ocorrera em São Domingos. Escrevendo tal texto quatro anos após a proclamação da independência do Haiti, o abade Grégoire voltava, também, a falar do Brasil, afirmando que a abolição da escravidão em São Domingos fora o elemento irreversível que traria o fim do sistema colonial (expressão sua) e da escravidão nas demais partes das Américas, assinalando que no Brasil, nas Bahamas e na Jamaica já havia experiências bem sucedidas de trabalho por empreitada. Ou seja, assinalava o exemplo haitiano como fator que parecia irreversivel para o caminho do progresso da humanidade em geral e do continente americano em particular, acenando ao mesmo tempo com o fim da dominação colonial e da escravidão. Restava saber, segundo ele, se o fim da escravidão se daria pelo modelo haitiano ou de forma gradual e progressiva. Tal preocupação de Grégoire reforça a densidade da repercussão da Revolução do Haiti (apontada por ele como paradigma positivo, diante da persistência do escravismo e intransigência dos senhores) que aparecia como um fator que - amedrontando ou trazendo esperanças - marcava as referências da época, entre amplos setores das sociedades americanas e européias.

No tocante à Revolução do Haiti, ficou conhecido o texto no qual Grégoire, em 1791, afirmou textualmente (pouco tempo antes do início da insurreição dos escravos):

"(...) que um dia nas costas das Antilhas o sol só iluminará homens livres e que os raios do astro que espalha a luz não cairão mais sobre ferros e escravos".11

Tal asserção causou verdadeira ira entre os setores colonialistas e escravistas da sociedade francesa, que passaram a associar o abade Grégoire aos fatos ocorridos na ilha de São Domingos. Mesmo explicando que dirigira tais palavras impressas apenas aos mulatos e negros livres, e reiterando que era, a princípio, a favor da extinção gradual do trabalho escravo (e não através de uma ruptura, do mesmo modo, aliás, que seus colegas da Sociedade dos Amigos dos Negros), Grégoire não renegaria aquela afirmação: pelo contrário, continuaria a lembrá-la pelo resto da vida, atribuindo a respon- 
12

A mesma questão fora abordada por H. Grégoire em outros pronunciamentos, como Mémoire en faveur des gens de couleur ou sang-mêlés de St.-Domingue, \&t des autres iles françoises de l'Amérique, adressé à l'Assemblée Nationale, Paris: Belin, 1789.

13

Tradução livre do trecho de H. Grégoire, De la liberté de conscience et de culte à Haïti, Paris: Baudouin, 1824, p. 42, apud Alyssa Goldstein Sepinwall, "Grégoire et Haïti: um héritage complique", In: Yves Bénot e Marcel Dorigny (dir.). Grégoire et la cause des Noirs (1789 - 1831), combats et projets, Saint Dennis: Société française d'histoire d'outre-mer, 2000, p. 109.

14

Tradução livre do trecho de H. Grégoire,

Observations sur la constitution du Nord d'Haiti et sur les opinions qu'on s'est formées en France de ce gouvernement, In: Yves Bénot e Marcel Dorigny (dir.). Grégoire et la cause des Noirs (1789 - 1831), combats et projets, Saint Dennis: Société française d'histoire d'outre-mer, 2000, p. 151 sabilidade do ocorrido nas Antilhas francesas às intransigências e violências dos grandes proprietários e seus representantes ${ }^{12}$.

A maneira mais eloqüente com que o abade Grégoire demonstrou não rejeição, mas solidariedade e adesão ao Haiti independente e ao exercício do poder por ex-escravos, ainda no calor dos acontecimentos, pode ser acompanhada através das relações que ele estabeleceu, ficando na França, com a ex-colônia francesa, sobre a qual ele afirmava sem meias palavras:

"Haiti é um farol elevado sobre as Antilhas, em direção ao qual os escravos e seus senhores, os oprimidos e opressores voltam seus olhares"13.

Já no periodo em que Toussaint Louverture era o chefe de fato de São Domingos (entre 1797 e 1802), Grégoire estabeleceu contato direto com ele, visando colaborar com os ex-escravos que agora assumiam o poder. Uma das dificuldades era a obtenção de religiosos para se instalarem na ilha caribenha. Toussaint, que tinha formação católica, solicitou a Grégoire auxilio para a organização da Igreja em São Domingos, dizimada ou dispersa após a insurreição, como aliás ocorrera com a maior parte da infraestrutura européia existente. Toussaint solicitara que se obtivesse um bispo e três padres: o próprio Grégoire não se dispôs a ir, mas aceitou ser intermediário e, após buscas infrutíferas, não conseguiu nenhum clérigo desejoso de se instalar nas Antilhas. Mas tentando suprir esta falta, o abade Grégoire fez sucessivos envios à Toussaint, através de abolicionistas, comerciantes, militares, viajantes, entre outros, de livros e impressos. Que publicações eram essas que Grégoire fez chegar aos ex-cativos? Segundo suas próprias palavras:

"Esses livros eram obras de piedade e de educação bem escolhidas e exemplares das que eu havia publicado sobretudo em favor dos Africanos, como, entre outras, o escrito sobre La traite et l'esclavage des noirs et des Blancs par un ami des hommes de toutes les couleurs e recentemente 0 Manuel de piété à l'usage des hommes de couleur."14

Ou seja, o ex-bispo de Blois colocava-se solidário com a luta pelo fim da escravidão no Haiti (e também com o exercício do poder pelos antigos cativos após o fim do escravismo) e fundamentava tal solidariedade a partir de uma ótica cristã e iluminista, empenhando-se para que a nova situação se estabelecesse dentro dos padrões civilizatórios e religiosos ocidentais, através do estímulo das Luzes, da educação e da prática do catolicismo. É significativo ver a linha de coerência do abade Grégoire (que the custou perseguições e ostracismo na França), contra o preconceito racial e escravidão, e em seguida também de solidariedade aos escravos rebelados, bem como de apoio efetivo ao Haiti independente, embasado em sua visão de mundo fundada sobre a fraternidade revolucionária e cristã, imersa naquele contexto histórico.

Grégoire estabeleceu, assim, contatos com os principais líderes da Revolução do Haiti, relações que nem sempre eram fáceis, seja pela distância geográfica e das comunicações, mas também por distâncias políticas e culturais. Em relação a Henri Cristophe, por exemplo, este abade francês criticou duramente sua opção pelo regime monárquico, o que não impediu que este ex-escravo e novo governante haitiano mandasse comprar em Londres 200 exemplares do livro De la litterature des Nègres... em 1814, para serem distribuidos pelo país, ao mesmo tempo em que fez inserir trechos deste livro em publicações impressas no Haiti. 
15

Sobre a relação entre Grégoire e o Haiti recém-independente ver o artigo de Alyssa $\mathrm{G}$. Sepinwall, cit., de onde retiramos as informações deste parágrafo.

16

H. Grégoire, De la noblesse de la peau ou Du prejugé des blancs contre la couleur des Africains et celle de leurs descendants noirs et sang-mêlés, Paris : Éditions Jerôme Millon, 1996 $\{1826\}$. Os trechos citados foram livremente traduzidos.

17

Idem, cap. VII, p. 111

18

Idem, cap. 5, p. 88

19

Idem, cap. 6, p. 102.

20

Idem, cap. III, p. 55.
Grégoire correspondeu-se também com os dirigentes do governo do presidente Jean-Pierre Boyer, que o convidou para ser bispo do Haiti em 1818, convite novamente recusado pelo abade, que alegou sua idade avançada. Mesmo assim, Boyer colocou na sala de governo um retrato de Grégoire, a quem ele comparava, em grandeza e importância, a frei Bartolomeu de Las Casas. Nesse período, o abade Grégoire estabeleceu significativa correspondência epistolar com membros da nova elite haitiana, bem como colaborou na imprensa francesa, combatendo todos os preconceitos raciais, defendendo a causa dos negros e do Haiti. Entretanto, quando os governantes haitianos, na mesma época, conseguiram estabelecer um tratado de reconhecimento da independência com a França em 1825 (durante a Restauração monárquica), o retrato de Grégoire foi logo retirado do gabinete presidencial de Boyer, gesto que deixou o abade vivamente magoado 15 .

Nos anos 1820, seus últimos de vida, Grégoire manteria e daria contornos mais nítidos a seu combate contra diferentes formas de preconceito e, ainda, pela possibilidade de exportação do modelo haitiano. No livro De la noblesse de la peau ou du préjugé des blancs contre la couleur des Africains et celle de leurs descendents noirs et sang-mêlés, de 1826, dividido em sete capítulos, constam algumas dessas idéias ${ }^{16}$. Ele faz referência, por exemplo, à Santa Aliança dos Povos ${ }^{17}$, numa contraposição clara à internacionalização das dominações aristocráticas, monárquicas e européias centradas na Santa Aliança. Alerta para a possibilidade de que, com a manutenção dos rigores da escravidão em várias partes das Américas, surja em cada colônia ou país um Spartacus, um Toussaint Louverture ${ }^{18}$ que, à frente dos escravos, tomariam pela força aquilo que thes era negado pelo direito. E tal possibilidade se reforçava na medida em que:

"A Revolução Haitiana, pelo fato apenas de sua existência, terá talvez uma grande influência sobre o destino dos Africanos no novo mundo".

Fica evidente, pois, a caracterização do exemplo e do modelo haitiano, que gerara, a seu ver, um evento fundador, portanto irreversivel, cujas repercussões poderiam se alastrar e gerar conseqüências concretas, de acordo com as condições de cada localidade. Mesmo sem discutir, nesse escrito, as contradições internas do Haiti pós-independência, ele apontava para a força de sua significação externa, isto é, internacional, na composição daquilo que ele enxergava como a necessária Santa Aliança dos Povos. Ao mesmo tempo, Grégoire dirigia tais palavras como tentativa de convencer os proprietários e as autoridades a empreenderem, de forma gradual, o fim do tráfico e da escravidão.

Ainda no mesmo livro o abade Grégoire invoca o exemplo esclarecedor e virtuoso de pensadores católicos em territórios escravistas, citando, entre outros, o padre Antonio Vieira ${ }^{19}$, de quem parecia conhecer as obras. E retoma sua afirmação de que nos domínios espanhóis e portugueses nas Américas, apesar da enorme quantidade de escravos, estes não tinham uma sorte tão dura. Explicando tal característica por dois fatores: o espírito religioso que incentivou atividades de educação e de liberdade (alforria); e, como conseqüência, assinala a existência de negros e mulatos, naquelas localidades, que eram advogados, militares, médicos, padres e até bispos $^{20}$. Vemos ai um conjunto de três questões, a saber: o preconceito racial, a miscigenação e uma espécie de democratização étnica da sociedade. São questões que, embora próximas e relacionadas, têm suas lógicas 
David Brion Davis, 0 problema da escravidão na cultura ocidental, Rio de Janeiro: Civilização Brasileira, 2000.

22

H. Grégoire, De la noblesse de la peau..., cap. 7, p. 116.

\section{3}

A Capela de Santa Ifigênia, construída em 1747, na então rua dos Ferradores, centro do Rio de Janeiro, pertencia a uma "confraria de pretos minas" e de "pouca fortuna", isto é, à Irmandade de Santa Ifigênia e de Santo Elesbão, cf. padre Luiz Gonçalves dos Santos (Padre Perereca), Memórias para servir à História do Reino do Brasil, Belo Horizonte: Itatiaia, 1981 \{1825\}, t. I, pp. 57 e 128.

24

Panegyrico de Santo Elesbão e Santa Iphigenia, in Frei Francisco do Monte Alverne. Obras Oratorias. Rio de Janeiro: Laemmert, 1854, t. III, pp. 158 - 9 (referência válida para os trechos citados a seguir do mesmo sermão). Os sermões de Monte Alverne foram proferidos entre 1811 e 1836, embora só publicados, em sua maioria, em 1853-54. e ritmos próprios e não se confundem necessariamente, como já assinala o historiador David Brion Davis21. Neste caso, particularmente para o Brasil, Grégoire parece concluir, a partir de uma visivel miscigenação já acentuada no começo do século XIX, pela ausência de desigualdades mais acentuadas e até pelo enfraquecimento do preconceito racial.

Concluindo o livro, no qual desenvolveu e criticou a noção de nobreza da pele, Grégoire aponta para a outra nobreza, que considera a verdadeira: a da virtude, atributo de homens de todas as cores. ${ }^{22}$

\section{As palavras atravessam o oceano}

0 sermão que frei Francisco do Monte Alverne pregou aos membros da irmandade de Santo Elesbão e Santa Ifigênia serve como amostra de idéias e posições de parte do clero brasileiro diante da escravidão23. Num exercício comparativo constatamos que, ainda que sem a mesma contundência abolicionista ou republicana, e usando metáforas e alusões, é surpreendente perceber a sincronia de Monte Alverne, franciscano e pregador da Capela Imperial no Rio de Janeiro, com as proposições do abade Henri Grégoire, que, entretanto, não é citado.

Neste sermão Monte Alverne proferiu as seguintes palavras:

"Que estímulo para estes homens, que a religião chama seus filhos, e que uma parte de seus irmãos retém como escravos, poder sacudir seus pulsos apertados de algemas, e invocar estes protetores, que parecem tocar mais de perto sua condição por a conformidade de sua cor, e que advogam sua causa junto do Todo-poderoso!"24

Convém lembrar o público ao qual se dirigia o sermão: mulheres e homens negros, livres ou libertos, do Rio de Janeiro do início dos oitocentos. No trecho acima, como em seus demais discursos, o pregador franciscano não procura justificar a escravidão ou resignar os homens à sua condição. Ao contrário, ele fala em estímulo para que se quebrem algemas, tratando-os, pois, como protagonistas, inclusive para que advoguem sua causa, ainda que no âmbito da justiça divina. Além de assinalar: os que praticam a devoção destes dois santos identificam-se pela condição étnica.

Em seguida, reforça suas críticas à escravidão do seguinte modo:

"Vós que todos os dias insultais o Cristianismo, lede a história do seu estabelecimento, segui sua marcha, observai seus progressos; estudai a moral do Evangelho e as maravilhas da civilização, que ele só efetuou; e depois vinde blasfemar de uma crença, que arrancou a espécie humana da escravidão e da barbaridade."

Dirigindo-se neste trecho aos que possuiam escravos ou defendiam a escravidão, o pregador utilizava-se de um aparato conceitual típico da llustração, através da valorização do progresso e da civilização, em contraponto à barbárie e escravidão. Ele tratava desta última enquanto condição servil de trabalho e sujeição racial (não no sentido do despotismo político). Ao alertar para os recentes progressos do cristianismo, está implícita, pois, alusão a uma corrente renovadora da Igreja, sobretudo do ponto de vista social e político, que se acentua após a llustração setecentista e a Revolução francesa - embora, mais uma vez, não haja aqui menção explícita. Ele apontava, pois, para a noção de que a marcha inelutável do progresso e o espírito do cristianismo se incompatibilizavam com o trabalho escravo. 
Alinhavando, em seu discurso, a proximidade simbólica entre os dois santos venerados e seus seguidores daquele momento, o franciscano brasileiro afirmava:

"Heróis privilegiados, gênios sublimes, que honrastes a humanidade com as vossas lides gloriosas, vede aqueles que vêm hoje cobrir de votos o altar, em que vos colocou a perseverança mais provada. Imprimi em sua alma os grandes princípios, que atenuam a desigualdade das condições chamando todos os homens ao mesmo fim."

Mais uma vez o orador destaca a atuação dos fiéis - no caso, os negros e negras no Brasil escravista -, na medida em que é graças a eles que o culto a tais santos permanece, associado, aliás, aos grandes princípios da humanidade. Em seguida, destaca o papel que o cristianismo poderia ter para atenuar as desigualdades decorrentes da escravidão - mesma tecla em que bateria o abade Grégoire ao se referir especificamente ao Brasil.

Falando ainda dos seguidores de Santo Elesbão e Santa Ifigênia, o pregador continuava:

"Reconheçam eles na sublimidade da moral cristã, que os tem civilizado, a fonte desta liberdade, que só se encontra no equilibrio das nossas faculdades, e na prática da justiça. (...). Possamos penetrar-nos da excelência desta Religião, que descobriu a fonte da verdadeira nobreza."

A idéia de que a civilização cristã é o caminho para superação da escravidão e da barbárie, a valorização das faculdades intelectuais de todos (sem excluir, portanto, os negros), o realce da prática da justiça sob este ponto de vista e, sobretudo, a valorização da verdadeira nobreza (que segundo Grégoire era a da virtude, não a da cor da pele), permite uma interessante (e até certo ponto inusitada) aproximação das posições públicas deste pregador brasileiro com os postulados do abade Grégoire.

Não se tratava, pois, de exemplos mais conhecidos de pensamento liberal e crítico, como os do clero pernambucano, paraibano ou cearense envolvido nos movimentos republicanos de 1817 e 1824, mas das posições de um pregador do Rio de Janeiro e com espaço privilegiado na Corte. Embora o caso de frei Monte Alverne tenha sua peculiaridade, na medida em que ele nunca ocupou cargos parlamentares ou funções diretamente políticas, ao contrário de outros clérigos do período. Possuia, pois, uma certa autonomia intelectual, condicionada, está claro, pela sociedade da época. Estes condicionamentos, ou limites, decorrentes das relações sociais estabelecidas e do próprio enraizamento cultural da escravidão, bem como do peso demarcatório do ambiente político do Rio de Janeiro (com seu caráter de centralização política e controle social), fazia com que as referências mais diretas a autores e posições identificadas como republicanas ou abolicionistas fossem eliminadas. Entretanto, pode-se perceber, pela comparação acima, que muitas destas idéias, ainda que despojadas dos "perigosos" rótulos, eram adotadas e propagadas sob o véu de uma linguagem indireta.

Além da repercussão ou proximidade de idéias e posições, pode-se dizer que o abade Grégoire acompanhou de perto e até relacionou-se com figuras importantes do clero brasileiro. Às vezes negativamente, em contraponto, como as referências que faz no seu famoso livro De la litterature des Negres... com críticas às posições do bispo José Joaquim da Cunha Azeredo Coutinho (1742 - 1821) por sua defesa da escravidão e do tráfico, explicitada por este, particularmente, na obra Analyse sur la justice du commerce $d u$ 
25

Tradução livre do trecho de H. Grégoire, De la litterature des Nègres..., p. XI.

\section{6}

Verbete sobre José Joaquim da Cunha Azeredo Coutinho, Innocencio Francisco da Silva e Brito Aranha.. Diccionario Bibliographico Portuguez. Lisboa: 23 volumes, Imprensa Nacional, 1858 - 1914 (edição em CD-ROM, Lisboa: Biblioteca Virtual dos Descobrimentos Portugueses, 09, Comissão Nacional para as Comemorações dos Descobrimentos Portugueses, s.d.). vol. IV, letra J. rachat des esclaves de la côte d'Afrique, publicada em Londres em 1798. 0 fundador do Seminário de Olinda recebeu críticas contundentes de Grégoire:

"De nossos dias somente, através de aplicações forçadas, um português, desnaturando as Sagradas Escrituras, tentou justificar a escravidão colonial, tão diferente daquilo que, entre os hebreus, era quase um trabalho doméstico; mas a publicação de Azeredo passou da loja do livreiro para a o rio do esquecimento." 25

Avaliação do bispo francês que, aliás, não passaria despercebida por Inocêncio Silva em seu repertório bibliográfico ${ }^{26}$, mas que parece ter sido ignorada pela maior parte dos autores que estudou a obra "reformista" do bispo luso-brasileiro, cuja defesa da escravidão de certo modo aparece como naturalizada dentro do que seria o contexto cultural e social da época - sem levar em conta, portanto, as discussões que então se travavam em torno da escravidão, da economia política e da questão racial. Posições que não eram monolíticas nem no âmbito dos pensadores católicos, como se pode ver por este exemplo. Encerrando o trecho sobre Azeredo Coutinho, Grégoire afirma: "Os amigos da escravidão são necessariamente os inimigos da humanidade".

Entretanto, a seguir, o mesmo Grégoire faz curiosas e rápidas considerações sobre as relações raciais e sociais nos "estabelecimentos portugueses e espanhóis" nas Américas, afirmando que aí os negros são considerados como irmãos e que a religião tem o papel de suavizar as violências e contrastes. 0 que entra em contradição com sua afirmação anterior, de que os portugueses não consideravam os negros como seres humanos. De qualquer modo, a América portuguesa (e depois o Brasil) não ocupará local de grande destaque nas preocupações de Grégoire, embora se encontre dentro de seu foco de interesse.

É certo, pois, que uma personalidade como o abade Grégoire acompanhava periodicamente o que se passava no Brasil e, para isso, cultivava seus contatos. Exemplar neste sentido foi a correspondência e amizade que Grégoire procurou manter com um destacado integrante do clero luso-brasileiro, monsenhor Pedro Machado Miranda Malheiro, mais conhecido como monsenhor Miranda, que ganhou notoriedade por ter sido Inspetor da Colônia de Suiços de Nova Friburgo (RJ) nos governos de d. João VI e d. Pedro I.

Monsenhor Miranda teve cargos de relevo. Formado em Coimbra, foi Desembargador do Paço e da Mesa de Consciência e Ordem (1810), Chanceler Mor do Reino do Brasil (1817), além de responsável pela colônia de suiços em Nova Friburgo, da qual foi um dos principais implantadores. Após a independência, adotou a nacionalidade brasileira e tornou-se Chanceler Mor do Império e ministro do Supremo Tribunal de Justiça em 1828, falecendo no Rio de Janeiro em 1839.

Além dos cargos oficiais, monsenhor Miranda destacou-se em outras áreas. Combatente militar contra as tropas francesas na invasão da península ibérica em 1808, comandou o Batalhão de Voluntários de Nossa Senhora de Oliveira e as narrativas destas guerras destacam sua presença ativa. Tornou-se desde então ligado a d. João VI e, quando do retorno deste do Brasil para Portugal em 1821, acompanhou-o na comitiva e foi um dos que teve seu nome na lista dos que se viram proibidos de desembarcar em Portugal, por ordem das Cortes de Lisboa. Estabeleceu-se então definitivamente no Brasil onde revelou-se, nas duas primeiras décadas do século XIX, um dos principais defensores da vinda de colonos europeus, através de 
27

"2 Cartas do Abbade Gregório, antigo Bispo de Blois, escriptas ao Monsenhor Miranda pedindoIhe, em huma dellas, noticias biographicas de escriptores pretos e pardos". Arquivo Nacional (RJ) - Diversos SDH - Cx 1226, Pac 2, doc 24. Documentos classificados como Colonização de Nova Friburgo. Trechos destas duas cartas livremente traduzidos a seguir. Agradeço ao historiador Flavio dos Santos Gomes a indicação destes documentos. textos e de ações administrativas. Naquele contexto, a defesa da imigração européia equivalia à busca de alternativa, ainda que paulatina, ao trabalho do escravo africano.

Apesar de diferenças de posições políticas, monsenhor Miranda tinha em comum com o abade Grégoire a imersão naqueles tempos da era das revoluções, além da defesa do progresso e da civilização européia, através, entre outros pontos, da propagação da ciência e da valorização da cultura francesa. Tais posições, aliadas à fé cristã e a existência de um círculo de amizades em comum, justificam a ligação e correspondência que mantiveram, ainda que intermitente, por pelo menos duas décadas - e da qual foi possivel encontrar extratos em duas cartas do próprio Grégoire dirigidas ao monsenhor Miranda em 1815 e 182027.

A primeira carta, datada de Paris na véspera do Natal de 1815 e com quatro páginas, tivera como portador nada menos que Joachim Le Breton (1760 - 1819), chefe da Missão Artística Francesa que chegou ao Brasil em 1816, trazendo, como se sabe, expressivos nomes da vida artística como Jean-Baptiste Debret, Nicolas Taunay, Grandjean de Montigny, entre outros. Le Breton chegara a entrar na carreira religiosa, abandonando-a, porém, durante a Revolução Francesa, da qual foi ativo participante, exercendo cargos na área cultural. Le Breton e Grégoire eram membros do Institut de France, no qual conviviam harmoniosamente, embora Grégoire, como já foi dito, acabaria excluído desta agremiação por suas posições políticas. A segunda carta, escrita também de Paris, datada de18 de julho de 1820 (remetida em 24 de julho de 1821), com três páginas, parece ter seguido pelo Correio.

Nestas duas missivas consta que o abade Grégoire remetia seus livros ao Brasil e que recebia, na França, livros em português. Ao mesmo tempo, o abade francês, conhecido defensor da Revolução do Haiti, reafirmava seus pontos de vista que lhe custavam perseguições e indagava da existência de homens de letras negros e mulatos no Brasil. Esta correspondência revela a ligação entre dois homens que, apesar de posições diferentes, pertenciam a um mesmo meio cultural e encontravam-se imersos na era das revoluções. As palavras de Grégoire apontam neste sentido. Após destacar que os laços de amizade entre ambos mantinham-se há 20 anos (carta de 1820) e sobreviviam às distâncias, o clérigo francês afirmava:

Depois de nosso último encontro, Monsenhor, alguns séculos se passaram, pois as revoluções ocorridas nos dois mundos, os eventos acumulados, as tempestades que atravessamos bastam para preencher periodos de séculos; pessoalmente passei por provações que, quando se enfrenta corajosamente os abusos, quando não se sabe (como tantos outros e, digo com dor, como tantos eclesiásticos) transigir com os abusos e dar à sua consciência e aos princípios uma leveza mundana, nos vemos às voltas com todos os furores da calúnia e à raiva das perseguições. Após cerca de quarenta anos, sempre numa luta constante, defendi os oprimidos de toda cor, de toda \{ilegíve/\}, judeus, negros, mestiços, combati o Despotismo, o feudalismo e a Inquisição.

No mesmo trecho Grégoire reconhece que de suas atividades acumulou "nuvens de inimigos". Na carta anterior, de 1815, o abade francês já ressaltara:

(...) mas os sofrimentos, as vicissitudes das coisas humanas, as perseguições de todo gênero, os ultrajes, não mudaram e Deus ajudando não 
mudarão jamais nossos principios e nossos sentimentos, religião, virtude, amizade, Literatura, esses diversos objetos aos quais nossos espiritos \{ilegive/\}.

Em outras palavras, o abade Grégoire se colocava por inteiro em sua correspondência brasileira, reafirmando seus princípios e realçando os pontos em comum que encontrara com este monsenhor luso-brasileiro igualmente tocado pelas Luzes da llustração, embora atuando em contexto bastante diverso das lides revolucionárias de seu colega francês.

É sugestivo destacar que nas duas cartas Grégoire tratava da remessa de seus livros ao Brasil - o que indica um esforço seu neste sentido. $\mathrm{Na}$ correspondência de 1815 informa que enviara por Le Breton sua última obra, da qual acabara de sair tradução inglesa. Talvez por prudência o título não fosse citado na missiva, mas neste ano Grégoire publicara apenas De la traite et de l'esclavage des noirs et des blancs; par un ami des hommes de toutes les couleurs, Paris: Impr. de Egron, 1815, cuja tradução inglesa sairia no mesmo ano em Londres, editada por J. Conder. Ou seja, é possível constatar que na bagagem da Missão Artística Francesa vieram também, ainda que precavidamente, textos como este candente libelo contra o tráfico e contra a escravidão.

Do mesmo modo, na carta de 1820, Grégoire informava que estava enviando vários de seus escritos pelo Correio para monsenhor Miranda e pedia particular atenção e leitura crítica de um livro onde defendia a liberdade e pluralidade de culto: Essai historique sur les libertés de l'Église gallicane et des autres Églises de la catholicité, pendant les deux derniers siècles (Paris: Censeur, 1818), especialmente do capítulo referente à Igreja em Portugal, para o qual Grégoire solicitava a Miranda contribuição para correções de futuras edições. É interessante outro ponto em comum encontrado pelo abade francês com seu interlocutor luso-brasileiro, ao apoiar o que considera a "sábia decisão do Governo Brasileiro" de não restabelecer a Companhia de Jesus em suas terras.

Na primeira carta, o abade Grégoire assinalava que solicitara a Le Breton "(...) recolher para mim informações sobre escritores negros e mulatos e de procurar suas biografias". E pedia a monsenhor Miranda para que o ajudasse nestas pesquisas - embora não se saiba se ambos tenham tido tempo ou interesse em responder a Grégoire. Le Breton, envolvido nas disputas cortesãs luso-brasileiras, acabaria falecendo doente e desestimulado em sua residência na Praia do Flamengo, no Rio de Janeiro, três anos depois de desembarcar nos Trópicos. Monsenhor Miranda continuaria a galgar postos públicos, em meio a um contexto onde a simples menção ao nome do abade Grégoire viraria grave acusação política no Brasil escravista - como veremos adiante.

Entretanto, pode-se explicar tal solicitação do abade francês a partir da compreensão de sua própria obra, pois seu trabalho matriz, de 1808 , De la littérature des Nègres ou Recherches sur leurs facultés intellectuelles, leurs qualités Morales et leur littérature; suivies de Notices sur la vie et les ouvrages des nègres qui se sont distingués dans les Sciences, les Lettres et les Arts, se compunha de uma ampla coletânea de biografias e notícias críticas de homens negros que se destacaram pelo talento ou cultura ao longo dos tempos em diversos países. No mesmo livro, como já foi assinalado, Grégoire lamentava a ausência de nomes do mundo português - e podemos perceber aqui que, mais de uma década depois, ele ainda continuava à busca de tais dados para enriquecer suas teorias anti-racistas. 
28

Correspondance Politique du Brésil, despacho de 23/8/1831, vol. 13, Archives du Ministère des Affaires Etrangères, Paris.

29

Exposição da Intriga feita pelo cirurgião formado Joaquim José da Silva ao Doutor Joaquim Candido Soares de Meirelles. Rio de Janeiro: Typographia de Gueffier, 1831.
As repercussões, no Brasil da primeira metade dos oitocentos, das idéias de personagens como o abade Grégoire, mesmo que não fossem maioria no Parlamento nem guiassem os atos governamentais, poderiam ganhar leitores e receptores favoráveis nas igrejas e conventos que, por sua vez, serviriam de intermediários com outros setores da população, através inclusive da propagação oral (os sermões), tocando, assim, homens e mulheres oprimidos do ponto de vista étnico e social. Os caminhos das repercussões da Revolução do Haiti no Brasil poderiam ser intermediados, sinuosos e surpreendentes.

\section{Brasil 1831: os fios de uma trama}

0 abade Grégoire e o Haiti estiveram em foco na cena pública brasileira no início do periodo Regencial através da discussão sobre a existência de uma "Sociedade Gregoriana", isto é, de uma associação de cunho abolicionista., centrada na figura do cirurgião Joaquim Candido Soares Meirelles (1797 - 1868). A partir daí ocorreu um rumor generalizado e forte - um Grande Medo - em torno de uma possivel articulação de tipo haitianista (levante de escravos para abolição da escravidão de forma violenta) na capital da monarquia brasileira, três meses após a abdicação de $d$. Pedro I.

A respeito deste rumor que trouxe receio e preocupações coletivas à capital brasileira entre junho e agosto de 1831, sua amplitude pode ser dimensionada pelo fato do representante diplomático francês no Brasil, Edouard Pontois, notificar à Paris a disputa entre "deux chirurgiens mulâtres" que havia "excité vivement" a população do Rio de Janeiro28. Quanto ao impacto deste mesmo rumor, o próprio Meirelles relataria, com visivel constrangimento e contrariedade:

Um boato corre, há dias, pela Cidade que tem enchido a huns de pavor, e a outros de indignação, em cujo último numero me colloco. ${ }^{29}$

A existência de uma associação deste tipo naquele lugar e momento parece pouco provável, porém, mais do que averiguar a veracidade de tais afirmações, importa-nos aqui tratá-las em sua positividade, isto é, como um rumor que ocorreu e repercutiu - procurando compreender seus significados e usos naquele contexto, bem como as personagens e questões envolvidas.

Tudo começou com uma intrincada desavença pessoal envolvendo ciúmes, intrigas e o renome político de dois cirurgiões da Santa Casa da Misericórdia do Rio de Janeiro: Joaquim Candido Soares Meirelles e Joaquim José da Silva. Em sintese, este sentiu-se ofendido por comentários desairosos que aquele teria feito a seu respeito, em conversa informal na casa do então Regente e senador Nicolau Vergueiro, questionando sua bravura e sua participação efetiva nos acontecimentos de 7 de abril daquele ano, que resultaram na abdicação de d. Pedro I. Sentindo-se atingido pelos comentários de Meirelles, o mesmo Joaquim José da Silva, passou a espalhar para outras pessoas a seguinte informação, nas palavras de Meirelles:

Então explicou elle que eu era chefe de uma sociedade secreta, que tinha por fim o assacinato dos brancos, e o crusamento ds raças; e que elle sendo convidado para essa sociedade, foi, porém a ouvir o plano, oppos-se e não quiz fazer parte delle. (...) e depois de mais de 20 pessoas Ihe me disseram - creia que o Silva o atassalha por toda a parte, e quando alguém quer duvidar, elle até ameaça, dizendo - não quer crer, pois quando Ihe doer a pelle, então sentirão ${ }^{30}$. 
31

Nota de Meirelles nesse ponto: "Que sois covarde e vil calumniador."
Meirelles nega estas e todas as acusações que seu colega de trabalho faria em seguida e o chama de malvado, caluniador e tartufo, além de lamentar o "rancor e o ódio" que o movia.

É de se notar que a acusação, transformada em rumor público, compunha-se de três pontos: formação de uma sociedade secreta, assassinato de brancos e cruzamento de raças. Estes itens, portanto, tinham caráter de incriminação. Nesta ocasião Meirelles responderia apenas aos dois primeiros pontos, que envolviam crime, mas retomaria a discussão sobre miscigenação (que não era crime, mas que atingia os costumes de determinada parcela da população) em outra oportunidade, nas páginas do jornal Sentinela da Liberdade no Rio de Janeiro, de 1832. Note-se que, na percepção do diplomata francês, citada acima, ambos, Meirelles e Silva, eram mulatos.

0 que inicialmente era um rumor, transmitido pela oralidade, acabou se cristalizando no papel impresso, publicado por iniciativa de Meirelles, que assim tentava desarmar a intriga e a trama. Meirelles então enviou carta ao "Amigo e Collega" Joaquim José da Silva, em 3 de junho de 1831, fazendo-Ihe quatro perguntas, para esclarecer as imputações. A resposta de Silva (transcrita no impresso feito por Meirelles) contém as perguntas e respostas, além de aumentar e detalhar as acusações. Eis a carta de Joaquim José da Silva para Meirelles:

Recebi hoje 3 de Junho de 1831, huma carta, e na qual me diz que para credito meu, e seu convinha que eu declarasse: $1^{\circ} \mathrm{em}$ que circulo club ou ajuntamento propoz o assassinato dos brancos, e a necessidade de cruzamento das raças; $2^{\circ}$ quaes as pessoas, que se achavão presentes, e as que o impugnarão; $3^{\circ}$ qual o objecto da reunião, e quem a convocou, e para que fim; $4^{\circ}$ finalmente que fim tem essa associação, de que (diz) somos membros, ou por acaso nos achamos ahi.

Posto que julgue que Ihe há-de ser desagradável ouvir verdades duras, para o satisfazer, e para que não perigue o seu credito, responderIhe-ei, que quanto ao $1^{\circ}$ não fui convidado em club, etc., mas para huma sociedade, que trabalhava segundo o plano do Abade Gregoire, com quem me disse conversara muito em França, e que sabia bem como isso se fazia: este convite me fez na rua dos Inválidos em huma coixeira onde nos recoIhemos do Sol, e para não ser ouvido: se o plano de Gregoire he para o assassinato dos brancos, e crusamento das raças, o meu Collega o dirá, pois segundo me disse, com elle conversara, e sabia ${ }^{31}$.

Quanto ao 2 o bem sabe o meu Collega que nos achávamos sós, e ninguém o impugnou. Quanto ao $3^{\circ}$ não me dizendo, quem a convocou aqui, dice-me (declarando-me alguns sócios da de cá) que Barata e Sabino a tinhão ido estabelecer na Bahia, e que brevemente o Bahiano mudaria de linguagem acerca do objecto; e fim está dito no $1^{\circ}$, isto he do Abade Gregoire."

E temos aqui a figura do abade Grégoire que sai da penumbra dos não-ditos e é citada no âmago de uma disputa que repercutia de maneira intensa no Rio de Janeiro, capital da monarquia escravista nas Américas. 0 que mostra que as postulações desse clérigo francês sobre escravidão, Haiti e preconceito racial eram conhecidas e difundidas - e não apenas por impressos, mas pelos rumores e pela oralidade, que podiam ultrapassar os círculos das pessoas letrados.

A acusação de formar uma sociedade secreta era sensivel naquele contexto, pois, como é sabido, o afastamento do monarca do poder gerou, nos dois primeiros anos da Regência no Brasil, uma verdadeira explosão 
Marco Morel. As transformações dos espaços públicos: imprensa, atores politicos e sociabilidades na cidade imperial (1820 - 1840), São Paulo: Hucitec, 2005; Marco Morel. O periodo das Regências (1831 - 1840), Rio de Janeiro: Zahar, 2003

\section{3}

Marco Morel. Cipriano Barata na Sentinela da Liberdade, Salvador: Academia de Letras da Bahia / Assembléia Legislativa do Estado, 2001. da palavra pública e de formas de mobilização política, que se verifica pelo crescimento destas ondas de rumores, por motins em várias cidades brasileiras e, inclusive, por um notável aumento quantitativo e qualitativo da imprensa e de associações ${ }^{32}$. 0 crescimento do movimento associativo gerou entidades diversificadas como as filantrópicas, patrióticas, explicitamente políticas, maçônicas, culturais, corporativas, mutualistas, de estrangeiros, etc., algumas públicas, outras reservadas, outras secretas. Ao mesmo tempo, este surto associativo foi acompanhado de temor e tentativa de controle, por parte das autoridades.

0 acusador envolvia ainda dois personagens conhecidos da vida política brasileira, os cirurgiões baianos Cipriano Barata 33 (que se encontrava preso naquele momento, acusado justamente de haitianismo) e Francisco Sabino Álvares, que seis anos depois estaria à frente da rebelião em Salvador que levou seu nome, a Sabinada. É interessante destacar, entretanto, que Barata e Sabino eram adversários pessoais, em função de disputas políticas na Bahia, sendo que este encabeçara um manifesto contra Barata que, por sua vez, atribuía a Sabino a responsabilidade de ser um dos que havia tramado por sua detenção. Meirelles também chamaria atenção sobre este ponto, alertando sobre esta divergência, que tornaria difícil a convivência de ambos numa associação secreta.

Meirelles tomou então a providência de enviar cartas às três pessoas citadas na denúncia, pedindo que se pronunciassem publicamente. Perguntava aos três se o conheciam, se já haviam se reunido com ele e se faziam, juntos, parte de alguma sociedade secreta.

Cipriano Barata foi o primeiro a responder: preso na Fortaleza de Villegaignon, no Rio de Janeiro, remete carta datada de 16 de junho 1831, na qual diz que ficou "pasmado" com o pedido. Afirma então com toda polidez que não conhece Meirelles, nem é seu amigo, nunca conversou com ele, e ignora qualquer tipo de sociedade secreta.

A resposta de Francisco Sabino ainda não viera da Bahia (Meirelles redigiu o folheto em 23 de julho).

Ao abade Grégoire, Meirelles escreveu carta, datada de 8 de junho 1831, perguntando se the conhecia ou havia visto, freqüentado, se participava de alguma sociedade secreta da qual o abade seria chefe ou membro. Vale transcrever aqui o trecho inicial da missiva enviada pelo médico mineiro:

\section{"Sr. Abade Grégoire,}

Como tenho o direito de suppor em vós todas as qualidades de homem de bem, peço-vos que me acuseis recepção desta carta por meio dos jornaes de Paris, fazendo inscril-a, assim como vossa resposta (..)".

Relaciona em seguida as questões. E assina com fórmula de polidez:

"Vosso mui humilde e obediente servo, Soares de Meirelles, Doutor em Medicina, e em Cirurgia pela Faculdade de Medicina de Paris".

Entretanto, o abade Grégoire nunca receberia a carta, pois falecera em Paris a 27 de maio de 1831. E uma viagem entre Rio de Janeiro e Paris naquela época durava entre 45 a 60 dias. Meirelles explica que já havia remetido a carta, tendo-a mostrado antes a várias pessoas, quando leu no Diário do Governo "a noticia da morte daquelle respeitável ancião, antigo patriarcha da liberdade. Eu quando Ihe escrevi, não podia prever que estaria morto; porém a confiança, com que escrevi, dá bem a entender que não temia a resposta." 
Informações biográficas sobre Meirelles extraidas de Joaquim Manoel de Macedo. Anno Biographico Brazileiro, Rio de Janeiro: Typographia e Lithographia do Imperial Instituto Artistico, 1876.
E realmente o Diário do Governo de 13 de julho de 1831, jornal oficial das Regências, anunciava a morte do "célebre Abade Gregoire, que teve huma enfermidade mui dolorosa, e cujo fallecimento deo causa a huma polemica entre o Arcebispo de Paris, o Ministro da Instrução Publica, e mesmo o Presidente do Conselho dos Ministros, acerca do enterramento."

0 jornal oficial não fazia os elogios fúnebres habituais na retórica da época. Limitava-se a um ambivalente "célebre". É de se notar, em contraste, no caso de Meirelles, a maneira como ele se refere ao abade Grégoire, chamando-o de homem de bem, respeitável ancião e patriarca da liberdade - o que não era linguagem corrente no Brasil daquela época quanto ao personagem em questão. Tratava-se, como já foi dito, de um dos mais conhecidos integrantes da Revolução Francesa, que presidia a Assembléia Nacional no dia 14 de julho de 1789, que não escondia seu apoio e admiração pela Revolução do Haiti e pelo governo de ex-escravos, e que combatia de maneira explícita a escravidão e o preconceito racial.

Entretanto, Meirelles não esclarece se conheceu pessoalmente o abade Grégoire. Tal encontro não era impossivel, pois sabe-se que este cirurgião brasileiro era formado em Medicina pela Universidade de Paris, onde esteve em pelo menos duas ocasiões, 1817 e 1825, mesmo período em que Grégoire encontrava-se lá. De qualquer maneira, como foi visto, o médico brasileiro compartilhava o ponto de vista do abade Grégoire sobre o preconceito racial - mas dai a um complô do tipo haitiano há uma distância considerável.

Mas sem dúvida Joaquim Meirelles seguiu o exemplo do velho revolucionário francês em outro domínio, o da propagação da sociabilidade científica. Nascido em Minas Gerais, ele foi um dos fundadores da Sociedade de Medicina do Rio de Janeiro (mais tarde Academia Imperial de Medicina) e pertencia também à Academia Philomatica, à Academia de Ciências de Nápoles e à Sociedade Defensora da Liberdade e Independência Nacional e era maçom. Com a Maioridade de d. Pedro II envolveu-se na rebelião dos liberais de Minas Gerais em 1842, foi preso e deportado. Em seguida, Meirelles parece ter transformado sua atuação na cena política: foi nomeado Médico da Imperial Câmara e membro do Conselho de sua Majestade 0 Imperador, além de receber condecorações como as Ordens da Rosa, do Cruzeiro e de São Bento de Aviz. Ele seria um dos pioneiros no tratamento das doenças mentais no Brasil no Hospital D. Pedro II e faleceria em 1868 aos 71 anos ${ }^{34}$. Seu filho, Soares de Meirelles, seguiu também a carreira médica e um de seus netos, também chamado Soares de Meirelles, seria o discreto patrono do poeta Cruz e Sousa, já no início do século XX. De algum modo, Joaquim Candido Meirelles conseguira, com eficácia e obstinação, romper o cerco que se erguera contra ele, por ser mulato e anti-racista.

Aliás, é sugestivo assinalar a epígrafe que Meirelles usou no folheto ao se defender da acusação de haitianismo quando, de maneira lúcida, escoIheu uma frase das Máximas, de Carlet: "Il faut bien mépriser la calomnie, mais il ne faut pas moins rechercher les causes qui ont pu y Donner lieu." \{Tradução livre: É preciso bem desprezar a calúnia, mas é preciso também buscar as causas que permitiram que ela ocorresse).

Através destes exemplos em torno do abade Grégoire, em geral obscurecidos pela historiografia brasileira, é possivel afirmar que a Revolução do Haiti constituiu-se num vigoroso modelo político no Brasil no momento de construção inicial do Estado e da Nação que, ao lado de outros modelos e referências, servia como catalisador de disputas sociais e discussões políticas envolvendo a escravidão e o preconceito racial, questões cruciais para a definição dos rumos da sociedade e das identidades de seus cidadãos. 